\title{
LEWE, DOOD EN ONSTERFLIKHEID \\ IN DIE \\ WYSBEGEERTE
}

Aangesien Wysbegeerte hom met die werklikheid besig hou, die werklikheid soos dit gegee is, en aangesien alle wysgere deur alle eeue met dieselfde werklikheid te doen het, daarom, omdat lewe, dood en onsterflikheid(?) deel van hierdie werklikheid is, het ook die wysgere deur die eeue heen hespiegelinge oor hierdie aspek van die werklikheid gehad. Omdat ook die Skrifmatige Wysbegeerte met dieselfde werklikheid te doen het, wat dit in die lig van die Skrif wil bestudeer, daarom moet ook die Calvinistiese wysgeer hom besin op sake soos lewe, dood en onsterflikheid.

Van hierdie drie is slegs die onsterflikheid nie sintuiglik waarneembaar nie. Is dit nou daarom minder vatbaar vir oorpeinsing en bestudering as die ander twee? "Slegs sintuiglik waarneembare feite is hestudeerbaar", dit is die opvatting van die Positiviste. Hierop wou die Neo-positivis verbeter, want vir hom bestaan daar ook nie-sintuiglik waarneembare feite soos o.a. die waardes en die siel van die mens, en ook hulle is bestudeerbaar. Ons het waar. dering vir die kritiek van die Neo-positivis op die Positivis, maar self wil ons nie by die Neo-positivisme bly staan nie: Alles wat Cod geskape het en in die hand van die mens gegee het om daaroor te heers, is wetenskaplik bestudeerbaar. As studieveld lê daar dus voor ons die hele aardse skepping in sy veelkleurige rykdom van sub. jekte, objekte, relasies tussen subjekte en subjekte, subjekte en objekte en ook relasies tussen objekte en objekte. Daar is verder die wette, die relasies tussen wette en subjekte, wette en objekte. Ook is daar nog die strukture, samelewingsverbande, gemeenskappe, samehange, ens. ens. En in die veld van ondersoek lê ook lewe, dood en onsterflikheid.

Die Wysbegeerte bestee van die vroegste begin af tot vandag toe baie aandag aan die drie. Voordat ons egter die geskiedenis nagaan en vasstel wat die beskouinge hieroor is, is dit noodsaaklik om eers die eie beskouing weer te gee. Dit kan dan slegs verdiep word deur die lig van die geskiedenis daarop te laat val.

Lewe, dood en onsterflikheid: hierdie drie vorm in die tema 'n eenheid en lê op hierdie lesing 'n baie welkome beperking want, omdat van onsterflikheid alleen sprake is by die mens (en wil ons nog nie op hierdie stadium beweer dat ons onsterflikheid in sy ganghare betekenis aanvaar nie), daarom beperk die opskrif ons tot die beskouing slegs van die mens; en lewe, dood en onsterflikheid slegs by die mens. En dan nog is dit onmoontlik om reg aan die onderwerp in die bestek van een lesing te laat geskied, aangesien ons eintlik die geskiedenis van 26 eeue van denkontwikke. ling moet behandel, en dit kan net nie. Ons is derhalwe genoodsaak om ons eie menshe- 
skouing deeglik onder oë te neem en hierdie mensbeskouing te verdiep na ' $n$ verfrissende bad in die geskiedenis van die Wyshegeerte. Vandaar dat hierdie betoog hoofsaaklik die vorm van 'n geloofsbelydenis sal aanneem.

As ons 'n paar oomblikke stilstaan by ons eie mensbeskouing dan wil ons dit duidelik stel dat ook hier ons kennis van die .. Onsienlike" ons kennis van die sienlike bepaal. Ons mensheskouing moet Skrifma. tig wees en daarom moet dit gehou wees op die fondament van die Skrif. Deur dit te hou op die Skrif, is dit nie noodwendig teologies nie, want 'n Skrifwaarheid en 'n teologiese bevinding is nie dieselfde nie. Teologie is 'n wetenskap, dus mensewerk en derhalwe net so feill,aar soos alle ander wetenskappe en mensewerke. Die Woord van God daarenteen is die waarheid en onfeilbaar. Watter soort mens ek is, hepaal watter soort teologie ek sal hê; en die vorming van my menswees hang van haie faktore af, o.a. my huislike opvoeding en my vorming deur die kerk met sy katkisasie en Woordverkondiging. Aan alle teologie lê 'n lewens- en wêreldbeskouing ten grondslag; elke teoloog teologiseer vanuit 'n vooraf ingenome standpunt - dink maar aan die verskil tussen 'n Gereformeerde teoloog, 'n Rooms-Katolieke teoloog en 'n heidense teoloog. Vir ons fundering op die Skrif gaan ons ons stel op Skrifwaarhede, dic Skrif wat 'n geopende hoek is en deur almal gelees kan word. Die interpretasie van die Skrif geskied hier, soos in elke ander geval vanuit 'n bepaalde lewens- en wêreldbeskouing, i.c. die Calvinistiese lewens- en wêreldbeskouing, waar uitgegaan word van die beginsel dat die Byleel die Woord van God is, en God is die Waarheid; daarom is 'n heroep op die Woord dic einde van alle teëspraak. Ons wil ons mensheskouing vestig op hierdie fondament en hierin lê die groot verskil tussen ons en G. C. van Niftrik met sy ,Zie, De Mens", waarin hy 'n mensheeld wil gee deur 'n analise van die menslike natuur van Christus te mak waarvan Sy goddelike natuur losgemaak is. Hierdeur proheer hy om 'n mensheeld op te hou deur die vol. maakte mens, Christus, te analiscer na aan. leidling van die Skriftekening van Christus se menslike natuur; 'n mensleskouing wat dan ook volmaak moet wees. $U$ voel dat Van Niftrik van die Bybel 'n wetenskaplike handbock maak en dit mag nie; nog min. der is dit menslik moontlik om die twee nature van Christus te skei -. dit sou 'n vernietiging van Christus beteken! 'n Skrif. matige wetenskap wil op die Skrif gefundeer wees, maar dan ondersoek dit altyd iets kosmies van aard, iets wat binne die heersersterrein van die mens lê. En dit is hierdic iets wat ondersoek word wat die omvang en inhoud van cns kennis hepaal. Om jou egter te fundeer op die Skrif, is dit uiters noodsaaklik dat ons sal weet wat in die Skrif staan en daarom is Skriflesing 'n uiters noodsaaklike vereiste; daarsonder sou 'n beroep op dic Skrif nie moontlik wees nie. Vir 'n Skrifmatige mensleskouing moet ons ook weet wat die Skrif leer aangaande die mens. Hierdie kennis wat die Skrif ons bied, noom ons voor-wetenskaplike kennis en hiervan kan ons vir ons 'n wetenskaplike verantwoording gee. Dit sou ek, ook in navolging van Totius, Teo. logie won noem. Ons wil dus op ons voorwetenskaplike Skrifkennis as fondament die wetenskaplike gebou, ook m.b.t. die eie antropologie, ophou. Die inhoud van die wetenskaplike gehou, van ons mensheskouing, sal egter geheel en al hepaal word deur 
ons voorwerp van studie; die gegewe werklikheid, nl. die mens, nader bepaal: lewe, dood en onsterflikheid. 'n Mensbeskouing wat op die Skrif gegrond wil wees, het ek gegee in my Koers-artikel: Die Mens, die Liefde en die Sedelike. Ek hoef dit nie weer hier te herhaal nie; dit kan ek as bekend veronderstel. 'n Paar verdere lyne sal egter getrek moet word na aanleiding van Skrifgegewens.

$O_{p}$ die sesde skeppingsdag het God die mens geskape nadat die aarde toeberei was om hom te onlvang, en wel deur hom te formeer uit die stof van die aarde en in sy neus te blaas die asem van die lewe. God het die mens na sy beeld geskape en hom laat heers oor die hele aardse skepping. God het die mens en slegs die mens geskape na Sy beeld en gelykenis. Hierin lê dadelik opgesluit die verskil tussen die mens en die res van die skepping; niks anders is na die beeld van God geskape nie. Tog is God nie hierdeur die makrokosmos en die mens die mikrokosmos, of God die makroteos en die mens die mikroteos nie nee, God is as Skepper en Wetgewer radi. kaal verskillend van die mens: niks van God is in die mens nie en niks van die mens is in God nie. Maar die mens is ook nie slegs minder volmakkte vorm en God die volmaakte vorm nie. Ons verwerp die Aristoteliese en Thomistiese standpunt dat die mens uit vorm en materie en Cod slegs uit vorm sou bestaan. Hierdie beskouing word deur die Skrif by die wortel afgesny. God het die mens na Sy beeld en gelykenis geskape en aan hom sy taak en terrein gegee, nl. heerskappy oor alle aardse skepsele. Die mens is as profeet, priester en koning geskape en toegerus met ware ken. nis, geregtigheid en heiligheid - hierin kan die heeldskap gesien word. God het die mens ook as 'n skepsel geskape wat nie verganklik is nie, wat nie sou sterwe nie; God het die mens met die ewigheid in sy hart geskape. Hy het dus 'n hesondere skepsel geskape wat verskil van alle ander skepsels: die mens is die enigste van die skepsels wat na die beeld van God geskape is en wat die ewigheid in sy hart het. Tog bly die mens skepsel, hy is geen god nie, besit geen goddelike eienskappe nie, hy is formeer uit die stof van die aarde en lewe deur die asem in sy neusgate geblaas. Saam met die res van die aardse skepping verskil die mens radikaal van God. Die wesensverskil tussen die mens en bv. die dier moet gesoek word in die skeppingskarakter van die mens. Deur hom na Sy beeld te skape, het God die mens „,kind van God" gemaak en daarom beteken ,menswees" in sy diepste „kind van God wees". Dat die mens as kind van God geskape is, beteken niks anders as dat God met die mens 'n verbond gemaak het nie: Ek sal vir jou 'n God wees en jy sal vir My 'n kind wees. God het as 't ware die hand van die mens gevat, waardeur die mens Sy hand kon neem en met God kon wandel. Die mens moet kragtens hierdie verbond, wat deel uitmaak van sy skeppingsaard, met God wandel, gehoorsaam wees aan Sy gehooie, hy moet luister na die stem van sy Skcpper. Gehoorsaamheid aan God se gebooie lê dus opgesluit in my menswees, lê in die skeppingsaard van die mens opgesluit. En in die gehoorsaamheid aan die wette van God en aan dic God van sy wette moet die mens profeet, priester en koning wees: verkondig, dien en heers. Hierdie drie ampte lê onafskeihaar opge. sluit in my mens-wees en as mens, dus as profeet, priester en koning, moet ek aan God en Sy wette gehoorsaam wees. By 
hierdie mens was daar van vryheid nog geen sprake nie. As ons die term mag gehruik, sou ons sê dat vryheid geen ,wesenstrek" van die mens is nie. Van vryheid is daar hy die mens eers sprake na die sondeval; now eers kon die mens verlos word van die slawehande. Gehoorsaamheid en vryheid kan dus nie op dieselfde vlak in ons menslseskouing geplaas word nie, gehoorsaamheid lê baie dieper as vryheid. Hierop kan ons tans egter nie verder ingaan nie.

Hierdie verhouding waarin God die mens tot Hom geplaas het, is spoedig deur die mens verbreek met die sondeval: „God weet dat as julle daarvan eet, julle oë sal oopgaan, sodat julle soos God sal wees deur goed en kwaad te ken" - Gen. 3 : 5 . En hier kom die influistering van satan waar. in die mens aangespoor word om te wil word soos Cod is, om self (jod te word. (Ongehoorsaamheid aan Sy gehooie, gebodsoortreding, 'n oorstap oor die wet heen na God toe om te word soos God is, die godwording van die mens - dit is sonde. $\mathrm{Na}$ hierdie verleiding van satan luister die mens en val in sonde. Van die mens se kant af verbreek hy die verhond wat God met hom gemaak het! Wat gebeur nou? Nou word bewaarheid die waarskuwing in Cen. 2 : 17: „want die dag as jy daar. van eet, sal jy sekerlik sterwe". En hiermee gepaard gaan die vloek wat uitge spreek word oor die hele aarde. Die mens word egter in die besonder getref, want hy sal terugkeer tot die aarde waaruit hy geneem is, "want stof is jy en tot stof sal jy terugkeer", Gen. 3 : 19. As Calvinis bely ons die algehele verdorwenheid van die mens na die sondeval. Nou is hy nie meer kind van God nie, maar kind van satan. Nou het die beeld van God in hom verlore gegaan. Nou kenmerk 'n funda- mentele ongelykheid die mens. Die mens met die ewigheid in sy hart sal nou die dood sterwe.

En tog laat God nie vaar die werke van Sy hande nie - ook die algehele verdorwe mens laat God nie vaar nie, die mens bly nog mens met alles wat dit impliseer. God soek die mens in die tuin op en kom direk ua die sondeval met die genadeleetoning, die verlossingswerk wat in Christus se vleeswording en kruisdood kulmineer. Verlossing is vrymaking van die sonde en daarom is daar van vryheid by die mens eers sprake na die sondeval. Eers nou kon die mens verlos word van die sonde en daarom is die term "vryheid" so vol van God se genade : vryheid, verlossing, genade - watter heerlike inhoud verkry hierdie term nie as dit gesien word in die lig van die Skrif nie! Vryheid hang derhalwe ten nouste saam met die herstel van die beeld van God in die mens deur die uitverkiesende genade van God, die moontlikheid aan ons geskenk om weer met God te wandel, om weer kind van God te word, om dus weer in die ware sin van die woord mens te wees. God is nie alleen Skepper nie maar ook Herskepper.

Ten diepste gesien, lê aan hierdie influistering van satan en die daarmee ge. paardgaande begeerte van die mens ten grondslag die illusie dat die mens die mag het om te kies. Tog was dit niks anders as ongehoorsaamheid nie, dit was gebodsoortreding, 'n oorskreiding van die grens tussen God en kosmos. In der waarheid het die mens geen kiesmoontlikheid nie. Hierdie sondige influistering van satan is trouens die grondslag van die strewe van die mens om soos God te word. Dit is die grondslag van die humanisme, wat alreeds hier in die paradys sy intrede in die kul- 
tuurgeskiedenis van die mens gemaak het; lumanisme is niks anders as die vergod. deliking van die mens nie, dit is die godwording van die mens. Ons moet die gedagte van die kiesmoontlikheid van die mens by die wortel afsny en daarteenoor plaas gehoorsaamheid, wandel met God, kind van God wees.

Hoe hierdie mens wat God geskape het, daar nou uitgesien het; waarmee God hom alles toegerus het; watter vermoëns God alles aan hom gegee het; daarop hoef ons hier nie breedvoerig in te gaan nie. Genoeg as ons sê dat God die mens volmaak toegerus het vir sy taak op aarde; hy is profeet, priester en koning; besit warc kennis, geregtigheid en heiligheid; hy kan die paradys bewerk en bewaak; hy kan oor die aardse skepping heers en dit beheers. Die mens is 'n wonderlike wese en daagliks verwonder ons ons al meer en meer oor hom.

Vir ons tema van belang is dat ons weet dat God die mens 'n lewende wese gemaak het deur in sy neusgate le blaas die asem van die lewe, waardeur liy 'n lewende siel geword het, dat hy geskape is met die ewigheid in sy hart, dus nie sou sterwe nie tensy hy van die verbode vrug cet, en dat, as hy na die sondeval van die hoom van dic lewe sou eet, hy sou lewe tot in ewigheid, maar dan in die smarte van die sonde. In hierdie wegdrywing uit die tuin lê dus vir die mens ook 'n genadedaad van God opgesluit.

Die mens is 'n lewende wese; hy is so geskape en sou nie sterwe as hy nie gesondig het nie. Hierdie Skrifwaarleid is vir ons onderwerp van grondleggende hetekenis. Dat God die asem van die lewe in die neus van Adam geblaas het, wil nie sê dat die mens daardeur 'n onsterflike siel het nie, mak ook nie van die mens 'n wese wat nie sou sterf nie. Die mens het daardeur 'n lewende siel geword. Die twee woorde mens en siel beteken hier presies dieselfde. Hierdie mens is geskape met die ewigheid in sy hart; die term hart dui hier die innerlike mens, die „ek", aan. Ons moet egter onderskei tussen die ewigheid van God en hierdie ewigheid in die hart van die mens, want hierdie ewigheid het wel 'n begin maar geen einde nie, dit is 'n ewige voortduurte. Goddelike ewigheid kan op niks kosmies toegepas word nie. Verder moet daarteen gewaak word om nie die woorde in Gen. 1, nl. „lewende siel" so te vertolk asof die mens nou uit twee self. standighede t.w. 'n liggaam en 'n siel, sou bestaan nie. Hiervan is daar geen sprake nie. God het nie eers 'n liggaam gemaak en toe 'n aparte selfstandigheid, die siel, daarin geplaas nie. Nee, God het die mens as lewende siel onverganklikheid gegee, hy het 'n lewende siel geword! Ons moet die siel-liggaamsbeskouing van die ganghare Wysbegeerte verwerp op grond van die Skrif, en gepaardgaande daarmee ook hulle probleemstelling oor die verhouding van siel en liggaam tot mekaar, sowel as die sg. probleem van wanneer die siel dan in die liggaam sou kom. In sy ewige voortbestaan verskil die mens dan ook geheel en al van alle ander aardse skepsele. Ook hulle lewe, maar hulle is geensins ewig. heidswesens in die sin soos die mens dit is nie. Van elke afsonderlike mens sê God: Ek het jou geken van voor die grondlegging van die wêreld af. Elkeen van ons is dan ook verantwoording aan God verskul dig, hoewel Sy genade en straf ook via die geslagte loop. Die ander aardse skepsele is ten volle tydelik kragtens hulle skeppingsaard, hulle is tydsgebonde. Daarom is die 
dood vir hulle 'n deel van hulle eieaard, hulle natuur; dit is vanaf hulle skepping 'n decl van hulle natuur; dit is ' $n$ natuurlike verskynsel dat plante en diere doodgaan, en hierdie verskynsel was ook aan Adam en Eva bekend. Dat dit so was, daarvan getuig die waarskuwing van God aan die mens dat hy sou sterwe as hy van die vrug. te van die bóóm eet, en die mens is geskape met ware kennis. Dit sou tog, menslikerwyse gesproke, absurd wees om die mens met iets te bedreig waarvan hy niks geweet het nie; en dit sê ek met alle respek.

Die mens word gestraf met die dood omdat hy gesondig het. Watter lig werp hierdie Skrifwaarheid op ons mensbeeld? En wat word hier onder dood verstaan? Ons kry nou te doen met die hele probleem van siel en liggaam en die onsterflikheid van die siel. En dit is veral hier waar ons moeilikheid begin, omdat hierdie woorde ook in die heidendom en in die paganistiese filosofie bekend is, en selfs 'n baie vername plek daarin inneem. Derhalwe is die gevaar van inleg- en uitlegkunde wesentlik sodra die denkers nie alleen bekend geraak het met die Skrif nie, maar ook toe denkers uit die heidendom bekeerd geraak het en die sintese-filosofie sy verskyning kon maak, waardeur 'n tradisie vir die Christendenker geskep is wat vandag nog ' $n$ belangrike rol in die eie tyd en denke speel. Wat die heidense wysbegeerte betref, dink ons aan die talle mensbeskouings waarvan sommige funksionalisties en ander weer substansia. listies was. Telkens is die siel as selfstandige eenheid gesien, of as 'n groep funksies wat as pseudo-ding gedink is, of as substansie wat saam met die liggaam as substansie die mens vorm. Hierdie mensbeskouinge het onderling baie gewissel, ook na gelang die denkers 'n monistiese of dua- listiese uitgangspunt gehandhaaf het. Vir haie moniste wat geen transendente erken het nie, was dit moeilik om die standpunt te handhaaf dat die siel onsterflik is ons dink hier maar aan die moeilikheid waarin Sokrates verkeer het oor die vraag na die hiernamaals. Die dualiste kon ook nog weer onderling verskil al na gelang hulle opvatting of daar ' $n$ tweedeling in die siel aanvaar moet word al dan nie. Sommige het geleer dat slegs die phren, die denkgees, uit die transendente kom, ander het hierby gevosg ook ander vermoëns soos die streef- en begeervermoëns. Hulle siclsbeskouing kon verder ook gepaard gaan met die leer van die pre-eksistensie van dic siel wat dan ook as onsterflik beskou is. Ons dink hier o.a. aan Plato wat op een tydstip geleer het dat die sicl, bestaande uit die rede, die strewe en die begeerte in die hemel bestaan het - hy stel dit in die beeld van 'n man wat met 'n kar en perde op die rug van die hemel ry en deur die linkse neiging van die begeervermoë die hele groep links trek sodat die hele siel later aftuimel na die aarde waar dit opgevang word deur die liggaam as grafkelder of tronk en waarvan dit slegs deur hoetedoening verlos kan word. By hom tref ons hier sowel die leer van die pre-eksistensie as die leer van die onsterflikheid van die siel aan. In sy finale konsepsie verwerp Aristoteles die leer dat die siel onsterflik sou wees, iets wat hy vroeër aanvaar het. Hy sien die siel nou as substansie wat as vorm saam met die liggaam as materie die mens vorm. As die liggaam ten onder gaan, sterf die siel ook. Nou was dit juis die beskouing van Plato wat die leiding geneem het gedurende die tydperk van die kerkvaders en die eerste fase van die Mirl. deleeue. Vandaar dat dit ons nie verbaas 
dat die leer van die onsterflikheid van die siel so 'n groot rol gespeel het by hierdie denkers nie. Selfs ' $n$ Thomas van Aquino, wat Aristoleles nagevolg het, het in hierdie verland onder invloed van Augustinus Aristoteles proleer korrigeer met die Skrif en sodloencle een van ons grootste sintesefilosowe geword. Ook in die moderne en huidige. filosofie speel die leer van die onsterflikheid van die siel, in sy tradisionele vertolking, 'n groot rol. Ook ons eie denke klcef so maklik vas aan hierdie tradisionele vertolking, 'n vertolking wat seer seker nie in die Skrif gegrond is nie maar per slot van sake in die Griekse Wyshegeerte.

God het die mens geskape. Hierdie mens is as eenheid geskape en bestaan nie uit verskillende selfstandige eenhede nie. Hoc sien hierdie mens daar uit? Ook dit leer die Skrif ons. In die eerste plek is Jaar die hart, iets wat in die Griekse Wysbegeerte geen plek het nie. Onder hart verstaan ons die innerlike mens, die ek, die religieuse sentrum van ons bestaan, die gcestelike wortel van alle tydelike manifestasies van ons lewe. En in hierdie hart as geestelike wortel is al die tydelike aspekte, funksies en vermoëns van die mens soos in 'n brandpunt saamgetrek, gekonsentreer. Dic mens besit derhalwe ook tydelike funksies hoewel die mens bo die tyd uitstyg, die tyd transendeer omdat hy die ewigheid in sy hart het. Hierdie deel van die mens kan ons sy uiterlike noem, sy funksieleer. Tussen die uiterlike en die innerlike is daar 'n baie intieme verband en samehang. Hulle is met mekaar verenig in wat ons dio funksiemantel noem. Hoewel ons hierdie drie onderskei, wil ons nie daardeur dic mens splits in verskillende selfstandig bestaande dele nie. Dic mens is kragtens sy skeppingsaard 'n cenheid. En hierdie mens, geskape na die beeld van God, is deur God toegerus met daardie innerlike religieuse drang om sy hele tydelike bestaan en die hele tydelike wêreld toe te spits op die diens van liefde tot God. Maar omdat die liefde vir God die liefde vir Sy beeld in die mens impliseer, daarom is die verskeidenheid van God se tydelike ordonnansies verwant aan die sentrale religieuse gebod van liefde, nl.: „Jy moet die Here jou God liefhê met jou hele hart, siel en verstand en jou naaste soos jouself". In sy diepste gesien, is die mens 'n religieuse wese, besiltende hart, funksieleer en funksiemantel. Hierdie mens is as ewigheidswese geskape en hierdie karakter-, of miskien wesenstrek van die mens het nie verlore gegaan met die sondeval nie; nieteenstaande die vloek van die dood, bly die mens mens en dus ook ewigheidswese; net soos al sy ander eienaardighede behoue gebly het, het ook hierdie behoue gebly. Wat met die sondeval geleur het, is dat die beeld van God in die mens verlore gegaan het; die mens is nie meer kind van God nie maar slaaf van satan; die mens kan nie meer met God wandel nie. Waar hy van nature God en sy naaste moes liefhê, daar haat hy van nature nou God en sy naaste. En dit is hierdie mens wat met die dood gestraf word.

Dit is dus haie duidelik dat die term dood m.b.t. die mens 'n heel besondere betekenis moet hê. Dit kan nie dieselfde beteken as dood, gesien as 'n natuurlike proses by plante en diere nie. Tog is dit so dat ons, deur die tradisie gebonde, gewoonlik oor die dood van die mens net so dink as oor die dood by die ander skepsele. Dit is dan ook in hierdie betekenis dat oor dood gespreek word in dic 
gangbare Wyshegeerte. Die Skrifmatige Wyshegeerte moet hiermee radikaal breek en die Skriftuurlike betekenis aan die woord gee. Die geskiedenis van die Wysbegeerte openbaar vanaf die Grieke tot vandag toe haie bespiegelinge oor die dood. Beerling kan dan ook 'n hoek skryf met die opskrif. Modeme Doodsproblematiek. In die kontemporêre Wyshegeerte speel die dood dan ook weer 'n besondere rol. Ons dink hier veral aan die oorheersende plek wat dit inneem in die Eksistensiewyshegeerte, daardie stroming wat vandag modefilosofie is en wat hom veral besin op die absurde, miskien op 'n absurde wyse. So 'n groot rol speel die dood in die Wyshegeerte van liv. Heidegger dat hy van die mens sê dat die mens vry is ten dode. Insiggewend oor die dood by Heidegger is deur prof. Zuidema in Philosiphia Reformata geskrywe, ook Beerling behandel Heidegger in die werk hierbo genoem. Vir Jaspers is die mens in hierdie lewe geworpe en die dood is 'n grenssituasie waarvoor die mens geplaas is en wat hy bewustelik in die oë moet staar sonder om dit te probeer ontvlug. Sartre weer is die volslae materialis vir wie die mens ten slotte 'n gat in die niks is, sorlat ook by hom daar 'n nag sonder dageraad vir ons geteken word. (Op al hicrdie mense se beskouinge kan vansellsprekend nie in die bestek van hierdic voordrag ingegaan word nie.

Laat ons ons eerder hesin op wat nou eintlik gebeur met die dood van die mens. God verbreek alleen tydelik die innige eenheid tussen die innerlike en uiterlike mens, die funksiemantel word tydelik afgelê. Ook word die innige verband tussen die mens en sy milieu verhreek. Vandaar die verskrikking van die dood vir die mens en vandaar die groot verskil tussen die dood van die mens en die dood van plant en dier. Maar hierdie verbreking is slegs vir 'n kort tydjie. Hierna volg die vereniging met die oordeelsdag, die opstanding uit die dood waarvan die Skrif spreek en waarin Christus ons ook voorgegaan het en hierdeur vir ons 'n duidelike beeld gegec het van die toestand na die opstanding. Bewyse daarvan dat die dood en die skeiding daardeur slegs sekondêr is, m.a.w. nie deel uitmaak van die skeppingsaard van die mens nie, vind ons ook in die gevalle van Henoch en Elia wat lewendig opgeneem is in die hemel. Verder is daar ook diegene wat die dood nie sal smaak nie, hulle wat met die oordeclsdag nog in lewe sal wees. Die dood is dus iets vreemds aan die skeppingsaard van die mens; dit is voorwaar 'n vloek wat die mens met die sondeval getref het. Maar die dood is dan ook geen blywende verskynsel by die mens nie, dit word opgehef deur die opstanding. Tog spreek dic Skrif ook nog van 'n tweede dood soos in Openl. 21 : 8. Ook dic Griekse Wyshegeerte ken 'n tweede dood, soos o.a. by Plutarchus wat ook hier funksionalisties gedink het. Hy sien die eerste dood as 'n skeiding tussen die liggaam wat beweeg word en die siel waarvandaan die beweging kom, terwyl by die tweede dood die hoogste deel van die siel wat uit die kerker van die liggaam bevry is weer die laere decl van hierdie siel op die maan agter laat om dan verder self na die son terug te keer. Die Skrif spreek oor die tweede dood 'n heeltemal ander taal. Bogenoemde teks lees soos volg: „Maar wal die vreesagtiges angaan en dic ongelowiges en die gruwelikes en moordenaurs en hoereerders en towenaars en afgodedienaars en al die leuenaars - - hulle deel is in die poel wat brand met vuur en swawel: dit is 
die tweede dood". Die twcede dood raak dus hulle wat nie uitverkies is nie, hulle wat verlore gaan. Maar ook hierdie dood hou nie die vernietiging van die mens in nie, ook nou nog geld vir die mens dat hy die ewigheid in sy hart het. Onderworpo wees aan hierdie dood, sluit net so heslis vernietig word uit!

Dood by die mens, Skrifmatig gesien, heteken dus weliswaar 'n skeiding. Tog staan in die Skrif die verbreking van die verhand waarin die mens as lewende siel dus soos hy, kind van God of nie - leef, die verhand waarin hierdie mens tot sy omgewing staan, voorop. Die aflegging van die liggaam is hier 'n sekondêre element. Dit blyk veral daaruit dat so iets slegs by die cerste dood voorkom. By die tweede doot is die hart of siel reeds met die liggaam herenig. Die liggaam, in hierdie sin, mag nie gesien word as die animale lewe van die mens nie, want so iets ken die Skrif nie. Die liggaam moet gesien word as die geheel van die funksies in hulle tydelike ontplooiing. Met die eerste door word die funksiemantel afgelê, maar mel die tweede dood is dit alreeds weer opge. neem.

Daar is egter 'n tweërlei troos vir dic Christen wat die eerste dood moet ondergaan. Die eerste is dat hierdie straf $\operatorname{tog}$ ook gepaard gaan met 'n seën. Wel word die samehang met die milieu sowel as die lewenseenheid met hierdie eerste dood vir die inens verbreek, maar terselfdertyd is dan ook die stryd tussen ,gees" en ,vlees", d.w.s. die stryd tussen die nuwe liefde en die ou haat wat sy lewe verteer het, op allei fronte verby. Hier op aarde hel daar uit die hart telkens bose begeertes opgekom, maar nou na hierdie dood woon die siel, gereinig van hierdie begeertes, hy die Here. Bowendien sal ook die liggaam, wat hier op aarde 'n doodsliggaam is, weldra die siel volg. Ook hierdie liggaam wat as „natuurlike" (d.w.s. 'n liggaam wat in Adam in sonde geval het, maar dan as funksiemantel gesien) liggaam in verderflikheid, oneer en swakheid begrawe is, is net so min as die siel prooi van die dood maar sal as 'n ,geestelike" liggaam, d.w.s. "n liggaam wat deur die gees van Christus heheers is, opgewek word.

En dit bring ons ten slotte by die term onsterflikheid. Ons het alreeds die aandag daarop gevestig dat die begrip „onsterflikheid van die siel" 'n paganistiese begrip is wat as sodanig geen grond in die Skrif het nie. Dit berus op 'n mensheskouing wat o.i. heeltemal onskrifmatig is. Vandaar dan ook dat ons die term in die begin met 'n vraagteken behandel het. Dit is tans ons taak om ook oor hierdie term helderheid te probeer kry en wel in die lig van die Skrif. Ook hier spreek die Skrif 'n duidelike taal. Onsterflikheid beteken: nie aan die mag van die dood - in die Skriftuurlike sin van die term - onderworpe wees nie. Vandaar dat onsterflikheid alleen aan God en aan hulle wat deur Hom oor die dood triomfeer, toekom. Onsterflikheid kom dan ook nooit ter sprake by mense voor die eerste dood nie. Maar dit is ook nie net 'n deel van hierdie mense wat onsterflik is nie, dit is die mens, die uitverkore mens, die volle verloste mens. En dit is alleen hierdie mense wat aan Christus behoort wat die onsterf likheid sal beërwe. Spreuke 12 : 28 sê : "Op die pad van geregtigheid is lewe, en die rigting van die pad is onsterflikheid". l Kor. 15 : 53 en 54 sê : „Want hierdie verganklike moet met onverganklikheid heklee word, en hierdie sterflike moet met onsterflikheid beklee word. En wammeer 
hierdie verganklike met onverganklikheid heklee is, en hierdie sterflike met onsterf. likheid beklee is, dan sal vervul word die woord wat geskrywe is : "Die dood is ver. slind in die oorwinning". En l Tim. 6 : 16, waar gespreck word van die verskyning van die Here Jesus Christus, sê van IJom: „wat alleen onsterflikheid besit en 'n ontoeganklike lig bewoon, wat geen mens gesien het nie of kan sien nie, aan wic toekom eer en ewige krag". Van onsterflikheid is daar in die Skrif slegs sprake by Cod en Sy uitverkore kinders. Om dus te veralgemeen en te sê dat die mens, en nog erger, dat die siel onsterflik is, is om 'n liewering te mak wat o.i. geen grond in die Skrif het nie, wat derhalwe geheel en al onskrifmatig is en dus glad nie in 'n Calvinistiese Wysbegeerte tuishoort nie. Vir helderheid moet hier nog bygevoeg word dat die term ,onsterflik wees" veel meer insluit as ,voortbestaan", want ook hulle wat verlore gaan, sal bly voortbestaan, maar dan as prooi van die tweede dood, want hoewel hulle onderworpe is aan dic tweede dood, word hulle nie daardeur vernietig nie. Die term ,verlore gaan" sluit derhalwe ook nie ,vernictig word" in nie.

Hierdie betekenis van mens, lewe, dood en onsterflikheid ken die nie-skrifmatige Wysbegeerte glad nie. Ook hierdie wysgere het met dieselfde werklikheid as ons te doen, maar in hulle Wysbegeerte kan die Skrif nie sy regmatige plek inneem nie - dit word in ongeregtigheid ten onder gehou. Ons daarenteen wil erns mak met dic Woord van God en 'n poging aanwend om die Wyshegeerte, in U lig" te sien en uit te hou, vandaar dat die Skrifwaarhede deurgaans aan ons siening ten grondslag gelê word. Ook vir die andersdenkende filosowe geld, net soos vir ons, dat hulle antropologie as onderdeel van die ontologie hulle siening van lewe, dood en onsterflikheid hepaal. Oor die eie ontologie kon uit die aard van die saak nie eintlik gespreek word nie, die antropologie is sleg: aangeraak by wyse van fundering vir die beskouing oor lewe, dood en onsterflikheid. Baie probleme hier, is nie angeraak nie; ons kon nie breedvoerig ingaan op die funksionalistiese mensbeskouing van die ganghare Wysbegeerte nie, met sy verdelinge van die mens in siel en/of gees $\mathrm{cn}$ liggaam, of op die substansialistiese mensbeskouing, w.o. die spiritualistiese sielsbeskouing wat self baie interessant is. Ses-entwintig eeue van geskiedenis van mensbeskouinge kon onmoontlik behandel word. ( )ns hoop dat u wel 'n blik kon kry in die ganglare beskouinge en dat $u$ ook onder die indruk gekom het van die mag van die tradisie. (Ons voel egter oortuig daarvan dat daar slegs een pad is vir die Calvinis om te hewandel, ook in die Wysbegeerte, en dit is om te probeer breek met die ganghare en om konsekwent en relormatories verder te werk. Laat ons, met alle waardering vir die werk van ons voorgangers, tog die standpunt huldig dat ons nie mag sweer by die woorde van menslike meesters nie maar alleen by die woord van God. „In U lig sien ons die lig”.

J. A. L. Taljaard.

P.U. vir C.H.O. 
GERAADPLEEGDE WERKE

Bavinck, J. H.: Het Raadsel van ons Leven. Bavinck, H.: Gereformeerde Dogmatiek, I-IV.

Beeriing, R. F.: Moderne Doodsproblematiek. Berkhouwer, G. C.: Dogmatische Studiën.

Dooyeweerd, H.: Reformatie en Scholastiek in de Wijsbegeerte.

De Wijsbegeerte der Wetsidee, I-III.

A New Critique of Theoretical Thought, I-IV.

Vernieuwing en Bezinning.

In the Twilight of Western Thought.

du Noüy, L.: Wij en onze Bestemming.

du Toit, J. D.: Diktate: Ensiklopedie.

Locus de Consummatione Saeculi.

Fechner, G. T.: Life after Death.

Gerbrandy, e.a.: Aspecten van de Dood in de Wetenschap.

Honig, A. G.: Handboek van de Gereformeerde Dogmatiek.

Jaspers, K.: Einführung in die Philosophie. Philosophisches Glauben.

Jordan, H. J.: De Causale Verklaring van het Leven.

Kapp, R. O.: Mind, Life and Body.

Kuyper, A.: Dogmatiek, I-V.
Landsberg, P. L.: Die Erfahrung des Todes.

Sassen, F.: Geschiedenis der Wijsbegeerte der Grieken en Romeinen.

Geschiedenis der Patristische en Middeleeuwsche Wijsbegeerte.

Geschiedenis van de Nieuwere Wijsbegeerte tot Kant.

Van Kant tot Bergson.

Wijsbegeerte van onze Tijd.

Scheepers, J. H.: Die Gees van God en die gees van die mens in die Ou Testament.

Spier, J. M. : Filosofie van de Onbekende God

Ueberweg/Heinze: Grundriss der Geschichte der Philosophie, I-V.

Van Niftrik, G. C.: Zie, de Mens.

Vollenhoven, D. H. Th.: Het Calvinisme en de Reformatie van de Wijsbegeerte.

Geschiedenis der Wijsbegeerte.

Diktate: Eisagoge.

Geschiedenis van de Wijsbegeerte.

Kort Overzicht van de Geschiedenis der Wijsbegeerte voor den Cursus Paedagogiek M.O.A.

Zuidema, S. U.: De Dood bij Heidegger. De Mensch als Historie. Nacht zonder Dageraad. 